\title{
CHEMICAL CHARACTERIZATION, HARDNESS AND TERMITE RESISTANCE OF Quercus Cerris HEARTWOOD FROM KOSOVO
}

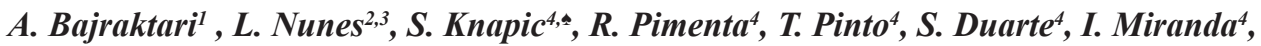 \\ H. Pereira ${ }^{4}$
}

In memoriam of Dr. Thomas C. MANNES

\begin{abstract}
Quercus cerris, the Turkey oak, is an oak species native to southern central and southeastern Europe, extending into southwestern Asia. It is present in a large extent in the forests of the Republic of Kosovo, and at present used mainly for bio-energy. The potential use of Quercus cerris wood for construction and higher value wood products has been investigated in the last years. However limited information is available on wood characteristics and performance, mainly regarding chemical composition and durability. The heartwood of Quercus cerris taken from 70-90 year-old trees grown in two sites in Kosovo was studied regarding resistance to termite attack, chemical composition and hardness. The heartwood contained only $6,7 \%$ extractives, with a small content of tannins. The wood density was on average 0,81 at $12 \%$ moisture content and Brinell hardness $36,2 \mathrm{MPa}$. It was classified as not durable against subterranean termites and therefore not suitable for external use in ground contact in termite areas unless adequately protected. Nevertheless, Quercus cerris wood showed adequate hardness and density for interior uses like flooring for domestic and commercial applications with moderate use.
\end{abstract}

Keywords: Brinell hardness, chemical analysis, density, Reticulitermes grassei, wood extractives.

\section{INTRODUCTION}

For centuries, European oaks have provided highly valued timber for carpentry, furniture making, construction and ship building. However, except for a few of the oak species e.g. Quercus robur and Quercus petreae, the knowledge on the technological properties of other species is still sparse. This is the case of Quercus cerris, the Turkey oak, a species native to southern central and southeastern Europe, extending into southwestern Asia (Danielewicz et al. 2014).

Quercus cerris is present in the forests of the Republic of Kosovo, which cover $42 \%$ of the country area and harbor a great potential in biomass for energy purposes and good quality timber for construction mainly from European beech (Fagus sylvatica) and oaks, with relevance to Turkey oak (Quercus cerris) (Bajraktari et al. 2014). Quercus cerris is one of the most used wood species in the country although mainly for bio-energy (Bouriaud et al. 2014). 
The possibility of using Quercus cerris wood for construction and in higher value wood products has been investigated in the last years (Bajraktari et al. 2014, Standfest et al. 2012a, Standfest et al. 2012b). The potential of Quercus cerris bark as a cork provider was also studied especially regarding one variety in Turkey, Quercus cerris $x$ cerris, that has a thick bark with high cork content (Sen et al. 2011, Sen et al. 2016). Several authors have attempted wood modification processes (heat and steaming treatments) to improve the wood dimensional properties and to homogenize surface color (Todaro et al. 2012, Todaro et al. 2013). Other wood properties were also investigated e.g. density and moisture (Monaco et al. 2011), and bending strength (Karastergiou et al. 2005). However, there is still limited information on Quercus cerris wood characteristics and performance, mainly regarding chemical composition and durability.

The biological deterioration of applied timber is often viewed as a limiting factor for its improved used in building. The natural durability of a wood species, defined as its inherent resistance to wood destroying agents, can vary widely depending on tree age, geographical origin, and growing conditions. Decay resistance also varies within the stem e.g. it tends to increase radially from pith to the heartwood-sapwood boundary and longitudinally from crown to base (Stirling et al. 2015), and is typically connected to the wood chemical composition, in particular, with the extractives present (Daniels and Russell 2007, Gierlinger et al. 2003, Pâques and Charpentier 2015). Nevertheless, the reasons of resistance to decay may not be directly translated into resistance to insect attacks: for instance, Taylor et al. (2006) found that the total wood extractives amount was important but alone could not explain termite durability in Thuja plicata and Chamaecyparis nootkatensis, and Stirling et al. (2015) confirmed the findings for Thuja plicata. Density and hardness are also typically referred as influencing the natural resistance of wood to termite attack (Esenther 1997, Peralta et al. 2004, Arango 2006, França et al. 2016).

In the present work, the natural durability class for insect degradation, as defined by EN350 (2016) (Table 1), was determined for Quercus cerris heartwood from mature trees at harvest age grown in Kosovo. Subterranean termites from the species Reticulitermes grassei were used as models as they are accepted as the most dangerous insect species capable of degrading applied timber in Europe and elsewhere and their risk is expected to be higher in a changing climate scenario (Ewart et al. 2016). Tests were conducted according to EN 117 (2013) and the results obtained linked to the chemical analysis, density and Brinnel hardeness data obtained from paired test specimens.

Table 1. Wood durability classes to attack by subterranean termites according to EN350 (2016).

\begin{tabular}{|c|c|c|}
\hline Durability Class & Description & Attack level \\
\hline DC D & Durable & $\geq 90 \%$ "0 or 1" and max $10 \%$ "2"; no "3" or "4" \\
\hline DC M & Moderately durable & $<50 \%$ "3, 4" \\
\hline DC S & Not Durable & $\geq 50 \%$ "3, 4" \\
\hline
\end{tabular}

\section{MATERIALS AND METHODS}

\section{Site characterization and sampling}

Ten mature Quercus cerris L. trees were randomly selected and harvested from two naturally regenerated and unmanaged stands in the Republic of Kosovo: Blinaja (KB), located at $42^{\circ} 30^{\prime} 31^{\prime \prime} \mathrm{N}$ $-42^{\circ} 30^{\prime} 38^{\prime \prime} \mathrm{N}$ and $20^{\circ} 59^{\prime} 06^{\prime \prime} \mathrm{E}-20^{\circ} 59^{\prime} 15^{\prime \prime} \mathrm{E}$ at $650-697 \mathrm{~m}$ of altitude, and Duboçak (KD) at $42^{\circ} 51^{\prime} 20^{\prime \prime} \mathrm{N}-42^{\circ} 51^{\prime} 23^{\prime \prime} \mathrm{N}$ and $20^{\circ} 43^{\prime} 50^{\prime \prime} \mathrm{E}-20^{\circ} 44^{\prime} 02^{\prime \prime} \mathrm{E}$ at $817-885 \mathrm{~m}$ of altitude. Both sites belong to a mixture of moderate continental and continental climates with $11,3^{\circ} \mathrm{C}(\mathrm{KB})$ and $10,4^{\circ} \mathrm{C}(\mathrm{KD})$ annual average air temperature, and $609,8 \mathrm{~mm}(\mathrm{~KB})$ and $604,8 \mathrm{~mm}(\mathrm{KG})$ average annual precipitation.

The trees were randomly selected in each stand and characterized by measuring total height and diameter at 1,3 $\mathrm{m}$ above ground (d.b.h., as the mean of two crossed diameters). Tree age was approximately 70 and 90 years, respectively at $\mathrm{KB}$ and $\mathrm{KD}$.

For stem quality characterization (Bajraktari et al. 2018) cross-sectional discs were taken at different stem height levels (base 1,3 m; 3,3 m; 5,3 m; 7,3 $\mathrm{m}$ and 9,3 m) and the logs between the first 
four discs were converted to boards. The boards were dried indoor under well ventilated conditions and the test specimens were taken from the heartwood. Unless otherwise described, the test specimens were obtained from the second $\log (1,3 \mathrm{~m}-3,3 \mathrm{~m})$.

\section{Chemical analysis}

Chemical summative analysis included determination of ash, soluble extractives in dichloromethane, ethanol and water, Klason and acid-soluble lignin, and the monomeric composition of polysaccharides. A total of 12 test specimens from the heartwood ( 6 from KB and 6 from KD) with $50 \times 25 \times 15 \mathrm{~mm}$ were individually analysed following procedures adapted from TAPPI standard methods (TAPPI 2004).

The test specimens were ground with a knife mill (Retsch SM200), sieved (Retsch ISO9001) and the 40-60 mesh fraction was kept for analysis. The ash content was determined by incinerating $1 \mathrm{~g}$ of the sample at $525^{\circ}$ overnight and weighing the residue (TAPPI 15 os-58).

The determination of extractives was adapted from TAPPI $204 \mathrm{~cm}$-97, using a Soxhlet system with dichloromethane, ethanol and water during $6 \mathrm{~h}, 16 \mathrm{~h}$ and $16 \mathrm{~h}$ respectively. The extractives solubilized by each solvent were determined by mass difference of the solid residue after drying at $105^{\circ} \mathrm{C}$. The lignin content was determined in the extracted samples by acid hydrolysis with $72 \%$ sulphuric acid following TAPPI T $222 \mathrm{om}-02$. Klason lignin was determined as the mass of the solid residue after drying at $105^{\circ} \mathrm{C}$ and the acid-soluble lignin was determined by the absorbance at $206 \mathrm{~nm}$ using a UV/VIS spectrophotometer (TAPPI Useful Method UM 250). The monosaccharides including neutral sugars and uronic acids as well as acetates were quantitatively determined in the hydrolysis liquor by High Performance Anion Exchange Chromatography. All determinations were made in duplicate samples.

\section{Ethanol-water extracts}

The ethanol-water extracts were prepared using $0,5 \mathrm{~g}$ of the sample and $20 \mathrm{ml}$ ethanol/water $(50 / 50$, $\mathrm{v} / \mathrm{v}$ ), for $30 \mathrm{~min}$ at $40{ }^{\circ} \mathrm{C}$ in an ultrasonic bath. After filtration, the supernatant extract was used to determine the contents in total phenolics, condensed and hydrolysable tannins and flavonoids.

The total phenolics content was estimated according to the Folin-Ciocalteu method using gallic acid as a standard (Singleton and Rossi 1965, Miranda et al. 2016). Total flavonoids were quantified by an aluminium chloride colorimetric assay, and the results were expressed as mg of $(+)$-catechin equivalents on a dry extract base (Jia et al. 1999, Miranda et al. 2016). Tannin content was determined by the vanillin-H2SO4 method, and the results were expressed as $\mathrm{mg}$ of $(+)$-catechin equivalents on a dry extract base (Abdalla et al. 2014, Miranda et al. 2016).

\section{Brinell hardness}

Brinell hardness perpendicular to the grain was evaluated according to EN 1534 (2010) with test specimens with the following dimensions: $40 \times 40 \times 10 \mathrm{~mm}$. Seven replicates from the second log of each tree felled and seven extra replicates from the first and third log of one tree per site in a total of 49 replicates for each location.

The tests were conducted at $20{ }^{\circ} \mathrm{C} \pm 2{ }^{\circ} \mathrm{C}$ and $65 \% \pm 5 \%$ relative humidity, using a universal machine AG 250KNIS-MO from Shimadzu, capable of measuring the applied load with an accuracy of $1 \%$. The test specimens is set to the machine table and a $10 \mathrm{~mm}$ steel ball indented into the surface of the wood at a steady and constant force in order to achieve $1 \mathrm{kN}$ in $15 \pm 3 \mathrm{~s}$. The load was maintained for $25 \pm 5 \mathrm{~s}$ and, after removal, the indentation was measured on images acquired immediately after testing with an Olympus SZX-ZB12 stereoscopic microscope and Olympus DP-Soft software. Crossed diameters ( $\mathrm{d} 1$ and $\mathrm{d} 2$ ) were measured to evaluate the size of the deformation inflicted by the ball. The Brinell hardness values (HB) were determined according to Equation 1 in MPa,

$$
H B=\frac{2 F}{N D\left(D^{2}-d^{2}\right)^{1 / 2}}
$$


Where $\mathrm{F}$ is the force applied $(\mathrm{N})$; $\mathrm{d}$ is the diameter of the indentation, in $\mathrm{mm}$ (average of two perpendicular diameters $\mathrm{d} 1$ and $\mathrm{d} 2$ ) and $\mathrm{D}$ is the diameter of the ball, in $\mathrm{mm}$.

\section{Determination of density}

Density was calculated according to the Portuguese Standard NP616 (1973) on the same test specimens used for the determination of the Brinell hardness and termite resistance. All specimens were conditioned for one week at controlled temperature and humidity $\left(20 \pm 1{ }^{\circ} \mathrm{C} ; 65 \pm 5 \%\right)$ and weighed. Dimensions of each specimen were then measured using a caliper and density calculated based on weight and volume and adjusted to $12 \%$ equivalent moisture content (EMC).

\section{Termite resistance}

The natural durability of the wood was evaluated according to the recommendations of EN350: 2016; therefore, the natural durability against the attack by subterranean termites was determined following the general procedure described in EN 117: 2012 with adaptations as described. Six replicates $(50 \mathrm{~mm} \times 25 \mathrm{~mm} \times 15 \mathrm{~mm})$ from the second $\log$ of each tree felled and six extra replicates from the first and third $\log$ of one tree per site in a total of 42 replicates for each location were tested.

The termites, Reticulitermes grassei (Clément), were collected from fallen logs from a forest area of Pinus pinaster Aiton, located $38^{\circ} 32.436^{\prime} \mathrm{N} 09^{\circ} 07.848^{\prime} \mathrm{W}, 18 \mathrm{~m}$ elevation. They were kept in Petri dishes with moistened filter paper inside a conditioned room $\left(24 \pm 2{ }^{\circ} \mathrm{C} ; 80 \pm 5 \%\right)$ for a maximum of 10 days. Colonies of 250 workers (plus 1-3 soldiers and 3-5 nymphs) were established in $750 \mathrm{ml}$ glass conical flasks with moisturized sand (Fontainebleau sand and water; 4:1 v/v) as substrate. The test specimens were placed over glass rings after installation of the termites in their respective containers, and the test run for eight weeks at $25 \pm 2{ }^{\circ} \mathrm{C}$ and $80 \pm 5 \%$ relative humidity. Ten $P$. pinaster untreated test specimens with the same dimensions were also included as virulence controls. After the exposure period, the test specimens were removed and cleaned and the survival rate (expressed in \%) was determined. A visual examination of the wood blocks was performed according to the criteria specified in the standard for the evaluation of the level of attack $(0=$ no attack; $1=$ attempted attack; $2=$ slight attack; $3=$ moderate attack; $4=$ strong attack). The test is considered valid if all virulence control test specimens reach a final level of attack of " 4 " and have an average survival rate above $50 \%$.

\section{Statistical analysis}

The descriptive statistic, correlation and regression analysis and analysis of variance (ANOVA or Student's t-test), where relevant, were performed using Microsoft Excel ${ }^{\circledR}(2010)$ and SigmaStat version 2.0 (Jandel Corporation).

\section{RESULTS AND DISCUSSION}

\section{Chemical analysis}

Table 2 displays the results regarding the chemical analysis of Quercus cerris heartwood. The analysis of variance showed no significant difference $(\mathrm{P}>0,05)$ between the two sampling sites for the mean values of total extractive content $(\mathrm{P}=0,415)$ and total lignin content $(\mathrm{P}=0,820)$. 
Table 2. Chemical composition ( $\%$ of the total dry mass) and monosaccharide composition (\% of total monosaccharides) of the heartwood of Quercus cerris from KB and KD.

\begin{tabular}{|l|c|c|}
\hline & KB & KD \\
\hline Ash & $0,88(0,21)$ & $0,97(0,26)$ \\
\hline Extractives & & \\
\hline Dichloromethane & $1,02(0,21)$ & $1,01(0,17)$ \\
\hline Ethanol & $2,12(0,41)$ & $2,65(0,86)$ \\
\hline Water & $3,29(1,06)$ & $3,33(0,86)$ \\
\hline Total & $6,43(1,33)$ & $6,99(0,94)$ \\
\hline Lignin & & \\
\hline Klason lignin & $23,23(1,36)$ & $24,00(1,41)$ \\
\hline Soluble lignin & $3,05(0,30)$ & $2,45(0,24)$ \\
\hline Total & $26,27(1,32)$ & $26,45(1,28)$ \\
\hline Monosaccharides & & $0,88(0,12)$ \\
\hline Ramnose & $0,74(0,08)$ & $1,69(0,08)$ \\
\hline Arabinose & $1,41(0,12)$ & $2,18(1,13)$ \\
\hline Galactose & $1,98(0,63)$ & $58,49(2,46)$ \\
\hline Glucose & $62,23(2,41)$ & $33,06(2,92)$ \\
\hline Xilose & $30,41(1,71)$ & $3,04(1,83)$ \\
\hline Manose & $2,07(1,55)$ & $1,87(0,13)$ \\
\hline Galacturonic acid & $1,93(0,14)$ & $0,21(0,01)$ \\
\hline Acetic acid & $0,23(0,01)$ & \\
\hline
\end{tabular}

Mean and standard deviation of 6 trees per site and 2 replicates per tree.

The heartwood of Quercus cerris presented the following average composition: ash 0,93\% total extractable substances $6,7 \%$ and total lignin $26,4 \%$. The extractives consisted mainly of polar compounds extracted by ethanol and water $(5,7 \%$ of heartwood), corresponding to $85 \%$ of the total extractives.

The striking chemical feature of Quercus cerris heartwood is the low content in extractives $(6,43 \%$ for $\mathrm{KB}$ and $6,99 \%$ for $\mathrm{KD}$ ). In fact, oaks have in general a large amount of extractives. For instance, Sousa et al. (2009) reported values of total extractives between $18,8-19,3 \%$ and total lignin $22,6-$ $23,7 \%$ for the heartwood of Quercus faginea. Carmona (2009) refers to total extractive contents between $14,8 \%$ and $15,7 \%$ (where the extractives in ethanol and water represent about $93 \%$ of the total extractives) in Quercus robur.

The chemical composition of the polysaccharides shows that glucose is the major sugar, corresponding to about $60,4 \%$ of the total monosaccharides present. The second most important sugar observed was xylose with a value of $31,7 \%$ which means that hemicelluloses in Quercus cerris heartwood are predominantly xylans with low contents of arabinose and acetyl groups.

The monomeric composition of polysaccharides is similar to that found for other oak woods in terms of predominance of glucose followed by xylose. Regarding Quercus faginea, Sousa et al. (2009) reported glucose and xylose values of $59,9 \%$ and $30,3 \%$ of the total monomers, respectively. A similar composition was reported for Quercus laurina and Quercus crassifolia woods with dominance of glucose $(52,3-56,7 \%)$ and xylose as the second most abundant sugar $(28,5-35,1 \%)$ (Ruiz-Aquino et al. 2015).

\section{Composition of ethanol-water extracts}

The results obtained for the ethanol-water extracts of Quercus cerris heartwood are presented in Table 3 . 
Table 3. Ethanol-water extracts of the heartwood of Quercus cerris from KB and KD: yield and content of total phenolics, condensed tannins and flavonoids. Mean and standard deviation of 6 trees per site.

\begin{tabular}{|l|c|c|}
\hline & Blinaja & Duboçak \\
\hline Extraction yield (\%) & $2,2(1,3)$ & $2,1(1,0)$ \\
\hline Total phenolics (mg GAE / g extract) & $338,8(152,8)$ & $284,2(97,9)$ \\
\hline Condensed tannins (mg CE / g extract) & $38,9(26,1)$ & $12,3(6,0)$ \\
\hline Flavonoids (mg CE / g extract) & $67,4(45,3)$ & $61,2(24,0)$ \\
\hline
\end{tabular}

There were no significant differences between the two locations, except for the condensed tannins that were higher in KB.

The total polyphenol content was on average $310,5 \mathrm{mg} \mathrm{GA} / \mathrm{g}$ of extract, the average tannins and flavonoids $25,6 \mathrm{mg} \mathrm{CE} / \mathrm{g}$ extract and $64,3 \mathrm{mg} \mathrm{CE} / \mathrm{g}$ extract. No hydrolysable tannins were found. Lavisci and Scalbert (1991) have reported levels of polyphenols of 3-4 mg / g of Quercus cerris wood.

Quercus cerris heartwood shows comparatively low amount of phenolics and tannins in comparison with other oaks, normally used in cooperage, and where high values of hydrolysable tannins and the non-existence of condensed tannins are reported.

\section{Brinell hardness and Density}

The results obtained for the Brinell hardness are presented in Table 4 as well as the average density of each group of test specimens. Significant differences were found between sites for density $(p<0,001)$ and Brinell hardness $(p<0,001)$ that were lower in the KD samples.

Table 4. Brinell hardness and density of the heartwood of Quercus cerris from Blinaja and Duboçak. Mean and standard deviation of 7 replicates, maximum and minimum values measured.

\begin{tabular}{|l|l|c|c|}
\hline \multicolumn{2}{|l|}{} & Blinaja & Duboçak \\
\hline \multirow{2}{*}{ Brinell hardness (MPa) } & Average (std dev) & $38,48(3,88)$ & $33,90(5,25)$ \\
\cline { 2 - 3 } & Minimum - Maximum & $29,99-48,45$ & $23,45-47,60$ \\
\hline \multirow{2}{*}{ Density } & Average (std dev) & $0,83(0,02)$ & $0,78(0,05)$ \\
\cline { 2 - 4 } & Minimum - Maximum & $0,79-0,88$ & $0,71-0,88$ \\
\hline
\end{tabular}

A positive correlation was found between density and Brinell hardness (Figure 1).

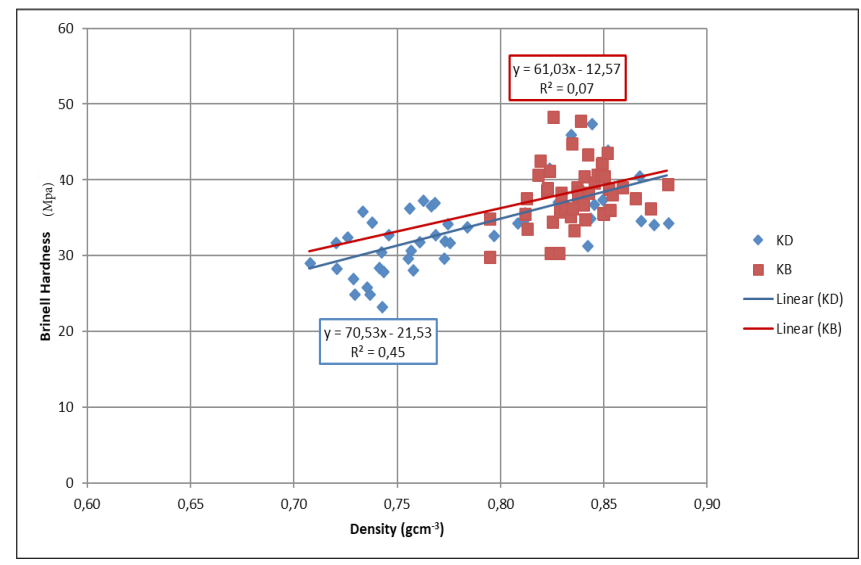

Figure 1. Relation between Brinell hardness and density of Quercus cerris heartwood. 
The regression between density and hardness was significant for $K D$ samples $\left(R^{2}=0,45 ; P<0,0001\right)$, while it was not significant for $\mathrm{KB}$ samples $\left(\mathrm{R}^{2}=0,07 ; \mathrm{P}=0,06\right)$.

The average density and Brinell hardness values from KB were close to the ones obtained on a previous study of wood from the same region (Standfest et al. 2012a, Standfest 2012b): 0,86 for density and 39,92 MPa for hardness. The average hardness values obtained for Quercus cerris wood are lower than values reported for Quercus faginea (50 MPa) or Quercus suber (56 MPa) but are nevertheless well within the required values for domestic flooring applications or commercial uses with moderate traffic (EN14354 2004).

\section{Termite resistance}

The results obtained for the rate of termite survival at the end of the test and grade of attack are presented in Table 5. The control test specimens of maritime pine $(n=10)$ had an average density of $0,66 \pm 0,07$ and at the end of the test showed an average level of attack of 4 and an average survival rate of $66,20 \% \pm 15,37 \%$.

Table 5. Wood density, survival and level of attack after 8 weeks of exposure to R, grassei of Quercus cerris heartwood from KB and KD. Mean and standard deviation of 6 replicates.

\begin{tabular}{|c|c|c|c|c|c|c|c|}
\hline \multicolumn{2}{|c|}{} & \multicolumn{3}{c|}{ KB } & \multicolumn{3}{c|}{ KD } \\
\hline Tree & Log & Density & Survival (\%) & $\begin{array}{c}\text { Level of } \\
\text { attack }\end{array}$ & Density & Survival (\%) & $\begin{array}{c}\text { Level of } \\
\text { attack }\end{array}$ \\
\hline I & 2 & $0,81(0,02)$ & $54,40(27,93)$ & $3,33(0,82)$ & $0,82(0,02)$ & $58,20(20,53)$ & $3,33(0,52)$ \\
\hline II & 2 & $0,79(0,02)$ & $67,27(14,59)$ & $3,67(0,52)$ & $0,79(0,01)$ & $33,53(26,74)$ & $3,33(0,82)$ \\
\hline III & 1 & $0,80(0,02)$ & $59,27(19,34)$ & $3,50(0,55)$ & $0,79(0,06)$ & $45,53(12,61)$ & $3,33(0,52)$ \\
\hline III & 2 & $0,77(0,01)$ & $53,47(21,56)$ & $3,67(0,52)$ & $0,87(0,02)$ & $45,93(14,32)$ & $3,17(0,75)$ \\
\hline III & 3 & $0,83(0,02)$ & $55,93(20,07)$ & $3,83(0,41)$ & $0,76(0,02)$ & $29,40(19,82)$ & $3,67(0,52)$ \\
\hline IV & 2 & $0,84(0,06)$ & $47,20(27,00)$ & $3,50(0,55)$ & $0,80(0,03)$ & $68,33(8,23)$ & $3,83(0,41)$ \\
\hline V & 2 & $0,81(0,01)$ & $33,00(12,54)$ & $3,00(0,55)$ & $0,79(0,02)$ & $16,93(16,67)$ & $2,83(0,75)$ \\
\hline \multicolumn{2}{|l|}{ MEAN (n=42) } & $0,81(0,03)$ & $52,93(21,94)$ & $3,50(0,55)$ & $0,80(0,04)$ & $42,27(23,26)$ & $3,36(0,66)$ \\
\hline
\end{tabular}

No significant differences were found between the Quercus cerris heartwood samples from both sites. On average, the survival rate was $47,60 \%$ and the level of attack 3,43 . No significant correlation was found between wood density and rate of survival. The percentage of test specimens graded " 3 and 4 " was determined and found to be $90,5 \%$ for KD and $97,8 \%$ for KB. Taking into account the criteria defined by EN350 (2016) to assign a subterranean termite durability class (Table 1) to a certain species of wood, the heartwood from Quercus cerris is classified as DC S (Not durable).

The fact that the species is susceptible to subterranean termites and has a heartwood classified only as "moderately durable" towards fungal decay (EN350 2016) leads to a recommendation of use preferably "out of ground contact" unless it is conveniently treated or otherwise protected, particularly in locations where termites are a risk.

Although other factors may influence the natural durability against termites, the susceptibility of Quercus cerris heartwood to termite attack is on line with the low extractives content found on the paired specimens (Table 2) and on the low content of tannins in the polar extracts (Table 3).

\section{CONCLUSIONS}

The heartwood of Quercus cerris has a low content of extractives namely of polar compounds of phenolic nature, namely of tannins. 
The Quercus cerris wood is described as "not durable" against subterranean termites and its use in outdoor environments in ground contact should be avoided unless adequate protection is made.

Quercus cerris wood shows adequate hardness and density for interior uses like flooring for domestic and commercial applications, with moderate use.

\section{ACKNOWLEDGMENTS}

The authors are grateful to the Kosovo Forest Agency and Regional Center for Vocational Training in Mitrovica for tree sampling. Centro de Estudos Florestais is funded by Fundação para a Ciência e a Tecnologia FCT (AGR/UID00239/2013). Sofia Knapic and Sónia Duarte acknowledge FCT for postdoctoral (SFRH/BPD/76101/2011) and doctoral (SFRH/BD/84920/2012) grants, respectively. COST Action FP1303 "Performance of biobased building materials" is also acknowledged.

\section{REFERENCES}

Abdalla, S.; Pizzi, A.; Ayed, N.; Bouthoury, F.C.; Charrier, B.; Bahabri, F.; Ganash, A. 2014. MALDI-TOF analysis of Aleppo pine (Pinus halepensis) bark tannin. BioResources 9: 3396-3406.

Arango, R.; Green III, F.; Hintz, K.; Lebow, P.K.; Miller, R.B. 2006. Natural durability of tropical and native woods against termite damage by Reticulitermes flavipes (Kollar). International Biodeterioration \& Biodegradation 57: 146-150.

Bajraktari, A.; Petutschnigg, A.; Ymeri, M.; Candan, Z.; Korkut, S.; Nunes, L.; Pereira, H. 2014. Forest resources and sawmill structure of Kosovo: State of the art and perspectives. Drvna Industrija 65 (4): 323-327.

Bajrakatri, A.; Pimenta, R.; Pinto, T.; Miranda, I.; Knapic, S.; Nunes, L.; Pereira, H. 2018. Stem quality of Quercus cerris trees from Kosovo for the sawmilling industry. Drewno 61(201). doi: 10.12841/wood.1644-3985.225.05.

Bouriaud, L.; Nichiforel, L.; Nunes, L.; Pereira, H.; Bajraktari, A. 2014. A property rightsbased analysis of the illegal logging for fuelwood in Kosovo. Biomass \& Bioenergy 67: 425-434.

Carmona, C.P. 2009. Variação do teor de extrativos e lenhina Klason em madeiras de Castanheiro e Carvalho que serviram de base para o envelhecimento de aguardentes vínicas. Master's Thesis, Escola Superior Agrária, Instituto Politécnico de Castelo Branco, Castelo Branco, Portugal.

Daniels, C.R.; Russell, J.H. 2007. Analysis of western red ceder (Thuja plicata Donn) heartwood components by HPLC as a possible screening tool for trees with enhanced natural durability. Journal of Chromatography Science 45: 281-285.

Danielewicz, W.; Kiciński, P.; Antosz, L. 2014. Turqey oak (Quercus cerris L.) in polish forests. Acta Scientiarium Polonorum Silv Colendar Rat Ind Lignar 13 (2): 5-22.

EN 117. 2012. Durability of wood and wood-based products - Determination of toxic values against Reticulitermes species (European termites) (laboratory method). European Committee for Standardization (CEN), Brussels.

EN 350. 2016. Durability of wood and wood-based products - Testing and classification of the durability to biological agents of wood and wood materials. European Committee for Standardization (CEN), Brussels. 
EN 1534. 2010. Wood flooring. Determination of resistance to indentation. Test method. European Committee for Standardization (CEN), Brussels.

EN 14354. 2004. Wood-based panels. Wood veneer floor covering. European Committee for Standardization (CEN), Brussels.

Esenther, G.R. 1977. Nutritive supplement method to evaluate resistance of natural or preservative treated-wood to subterranean termites. Journal of Economic Entomology 70: 341-346.

Ewart, D.; Nunes, L.; De Troya, T.; Kutnik, M. 2016. Termites and a changing climate. In "Climat change impacts on urban pests," P. Dhang (ed.), CAB International, UK, pp 80-94.

França, T.S.F.A.; França, F.J.N.; Arango, R.A.; Woodward, B.M.; Arantes, M.D.C. 2016. Natural resistance of plantation grown African mahogany (Khaya ivorensis and Khaya senegalensis) from Brazil to wood-rot fungi and subterranean termites. International Biodeterioration \& Biodegradation 107: 88-91.

Gierlinger, N; Jacques D.; Schwanninger, M.; Wimmer, R.; Hinterstoisser, B.; Pâques, L.E. 2003. Rapid prediction of natural durability of larch heartwood using Fourier transform near-infrared spectroscopy. Canadian Journal of Forest Research 33: 1727-1736.

Jia, Z., Tang, M., WU, J. 1999. The determination of flavonoid contents in mulberry and their scavenging effects on superoxide radicals. Food Chemistry 64 (4): 555-559.

Karastergiou, S.; Barboutis, J.; Vassiliou, V. 2005. Effect of the PVA gluing on bending strength properties of finger jointed turkey oakwood (Quercus cerris L.). Holz als roh-und werkstoff 64 (4): 339-340.

Lavisci, P; Scalbert, A. 1991. Quality of Turkey Oak (Quercus cerris L.) Wood I. Soluble and Insoluble Proanthocyanidins. Holzforschung 45 (4): 291-296.

Miranda, I.; Lima, L.; Quilhó, T.; Knapic, S.; Pereira, H. 2016. The bark of Eucalyptus sideroxylon as a source of phenolic extracts with anti-oxidant properties. Industrial Crops and Products 82:81-87.

Monaco, A.L.; Todaro, L.; Sarlatto, M.; Spina, R.; Calienno, L.; Picchio, R. 2011. Effect of moisture on physical parameters of timber from Turkey oak (Quercus cerris L.) coppice in Central Italy. Forestry Studies in China 13(4): 276-284.

NP 616. 1993. Madeiras. Determinação da massa volúmica. Instituto Português da Qualidade, Lisboa.

Pâques, L.E.; Charpentier, J-P. 2015. Perspectives for genetic improvement in heartwood size and extractive content in relation to natural durability and aesthetics in interspecific hybrid larch (Larix $\mathrm{x}$ eurolepsis). European Journal of Forest Research 134: 857-868.

Peralta, R.C.G.; Menezes, B.; Carvalho, A.G.; Aguiar-Menezes, E. 2004. Wood consumption rates of forest species by subterranean termites (Isoptera) under field conditions. Revista Árvore 28 (2): 283-289.

Ruiz-Aquino, F.; González-Peña, M.M.; Valdez-Hernández, J.I.; Revilla, U.S.; RomeroManzanares, A. 2015. Chemical characterization and fuel properties of wood and bark of two oaks from Oaxaca, Mexico. Industrial Crops and Products 65: 90-95.

Sen, A.; Leite, C.; Lima, L.; Lopes, P.; Pereira, H. 2016. Industrial valorization of Quercus cerris bark: Pilot scale fractionation. Industrial Crops and Products 92: 42-29.

Sen, A.; Quilho, T.; Pereira, H. 2011. Bark anatomy of Quercus cerris L. var. cerris from Turkey. Turkish Journal of Botany 35: 45-55.

Singleton, V.L.; Rossi, J.A. 1965. Colorimetry of total phenolics with phosphomolybdicphosphotungstic acid reagents. American Journal of Enology and Viticulture 16: 144-158. 
Sousa, V.; Cardoso, S.; Pereira, H. 2009. Caracterização da composição química da madeira de Quercus faginea. $6^{\circ}$ Congresso Florestal Nacional - A floresta num mundo globalizado, Outubro de 2009, Ponta Delgada, SPCF, Lisboa.

Standfest, G.; Wimmer, T.; Bajraktari, A.; Schnabel, T.; Petutschnigg, A. 2012a. Ausgewählte mechanische Eigenschaften der Zerreiche (Quercus cerris L.). Holztechnologie 53 (1): 5-10.

Standfest, G.; Schnabel, T.; Bajraktari, A.; Wimmer, T.; Ebner, M.; Petutschnigg, A. 2012b. Ausgewählte physikalische Eigenschaften der Zerreiche (Quercus cerris L.). Holztechnologie 53 (3): $5-9$

Stirling, R.; Morris, P.I.; Grace, J.K. 2015. Prediction of the decay and termite resistance of western red cedar heartwood. Forest Products Journal 65 (3/4): 84/92.

TAPPI. 2004. Tappi Standard Test Methods 2004-2005. TappiPress. Atlanta, GA.

Taylor, A.M.; Gartner, B.L.; Morrel, J.J.; Tsunoda, K. 2006. Effects of heartwood extractive fractions of Thuja plicata and Chamaecyparis nootkatensis on wood degradation by termites or fungi. Journal of Wood Science 52: 147-153.

Todaro, L.; Zanuttini, R.; Scopa, A.; Moretti, N. 2012. Influence of combined hydrothermal treatments on selected properties of Turkey oak (Quercus cerris L.) wood. Wood Science and Technology 46 (1-3): 563-578.

Todaro, L.; Dichicco, P.; Moretti, N.; D'auria, M. 2013. Effect of combined steam and heat treatments on extractives and lignin in sapwood and heartwood of turkey oak (Quercus cerris L.) wood. BioResources 8 (2): 1718-1730. 